\title{
Classification situations: Life-chances in the neoliberal era
}

\author{
Marion Fourcade $^{\mathrm{a}, *}$, Kieran Healy ${ }^{\mathrm{b}}$ \\ ${ }^{a}$ Department of Sociology, University of California-Berkeley, Berkeley, CA 94720-1980, USA \\ ${ }^{\mathrm{b}}$ Department of Sociology, Duke University, Durham, NC 27708, USA
}

\begin{abstract}
A B S T R A C T
This article examines the stratifying effects of economic classifications. We argue that in the neoliberal era market institutions increasingly use actuarial techniques to split and sort individuals into classification situations that shape life-chances. While this is a general and increasingly pervasive process, our main empirical illustration comes from the transformation of the credit market in the United States. This market works as both as a leveling force and as a condenser of new forms of social difference. The U.S. banking and credit system has greatly broadened its scope over the past twenty years to incorporate previously excluded groups. We observe this leveling tendency in the expansion of credit amongst lower-income households, the systematization of overdraft protections, and the unexpected and rapid growth of the fringe banking sector. But while access to credit has democratized, it has also differentiated. Scoring technologies classify and price people according to credit risk. This has allowed multiple new distinctions to be made amongst the creditworthy, as scores get attached to different interest rates and loan structures. Scores have also expanded into markets beyond consumer credit, such as insurance, real estate, employment, and elsewhere. The result is a cumulative pattern of advantage and disadvantage with both objectively measured and subjectively experienced aspects. We argue these private classificatory tools are increasingly central to the generation of "market-situations", and thus an important and overlooked force that structures individual life-chances. In short, classification situations may have become the engine of modern class situations.

(c) 2013 Published by Elsevier Ltd.
\end{abstract}

\section{Introduction}

Academics often remind others that familiar categories are difficult to question, but they are hardly immune to the problem themselves. Consider the case of social class. In general, contemporary approaches see classes as rooted in production, specifically the employment relation. This view descends from Marx, who argued that the beginning of class is one's relationship to the means of production. Notwithstanding the nuanced analysis of class relations in his political writings (e.g., in The 18th Brumaire and elsewhere), what stuck with sociologists was Marx and Engels's insistence that class analysis is, at its core-or "in

\footnotetext{
* Corresponding author.

E-mail addresses: fourcade@berkeley.edu (M. Fourcade), kjhealy@ soc.duke.edu (K. Healy).
}

the last instance," as people used to say-a matter of owning or not owning the means of production. Classes are defined antagonistically on that basis. Capitalists call the shots in the labor market and workers are forced to accept the terms on offer.

The core problem for later theorists has been to make sense of the rise of service and managerial occupations within this underlying relational structure. Scholars edged towards a Weberian view (Breen, 2005; Wright, 1985), eschewing a scheme of intrinsically antagonistic classes in favor of a more refined spectrum of class situations, or life chances, on various markets. People own (or do not own) different sorts of property, or they bring different skills to the market, or have different services to buy or sell.

In their efforts to build on Weber's insights and to reconcile theory with data, contemporary formulations of 
class theory became more precise, and tableaux of class membership more complex. Sociology's most influential statements on the subject, such as Wright (1985), Erikson and Goldthorpe (1993), and Grusky and Sørensen (1998), set out to operationalize the concept of class in a way that connected it to the process of socio-economic attainment. Largely framed by the methods and concerns of AngloAmerican mobility research, the challenge was to develop a class-based analysis that could make sense of the elusive "middle" of the American occupational structure. But this meant that contemporary class analysis remained close to its origins in that it still began with an analysis of the structure of positions in occupations, firms, and labor markets. We shall argue that this has made it hard to connect these theories to processes of social stratification that originate outside the sphere of production, in settings such as consumer credit systems, education, health services, and housing.

Of course, research on inequality shows other forms of social division beside class structure shape people's access to and experience of basic social institutions. Reliably, specific social groups-the poor, minorities, women, young people, and others, whether singularly or in various intersections and combinations-face a more restrictive set of choices, receive worse treatment, and experience worse outcomes than dominant groups in practically every institutional domain (Massey, 2008). The durability of these inequalities is explained, variously, by rational choices on the part of vendors trying to avoid catering to riskier individuals (Becker, 1971), the persistence of straightforward prejudice, or more subtle processes of symbolic violence, pragmatic disqualification, or systemic "über" discrimination (Reskin, 2012). In this view, modern markets reproduce inequalities that originate elsewhere in the social structure, in historical legacies, and in longstanding attitudes that differentiate between categories of people. The action of markets themselves does not contribute much to the formation of social hierarchies.

What if it did? What if we could make the recording, splitting and categorizing work done by markets and market technologies "good to think with" for the study of social inequality? The point is in some ways familiar. Occupational markets have long been structured by institutional devices such as licensing and credentialing systems, in addition to rules oriented to exclude certain kinds of people. But what makes the new market instruments so interesting is that they seem so much more democratic. Indeed, historically their appeal came, in part, from their purported ability to keep older forms of arbitrary or categorical discrimination at bay (Hyman, 2011; Poon, 2013). These new markets draw distinctions, too, but in a different way. Rather than protecting certain groups through the creation of rents and monopolies, they thrive on the market's competitive logic, demanding that people be measured against one another, and then separating and recombining them into groups for efficiency and profit. As with class, the process of differentiation is endogenous to the market itself. But unlike class, the action happens on the consumption side of the economy, rather than on the production side.
In this article, we focus more particularly on how the emergence and expansion of methods of tracking and classifying consumer behavior affect stratification through the allocation of credit. On the supply side, scoring agencies slice consumers into behaviorally-defined risk groups, and price offerings to them accordingly. On the demand side, consumers find themselves more or less comfortably fitting into these categories-which, by design, are not constructed from standard demographic classifications such as race and gender. At the intersection of this supply and demand, the increasing sophistication of credit scoring generates what we call classification situations: positions in the credit market that are consequential for one's lifechances, and that are associated with distinctive experiences of debt. These range from the exploitative to the dutiful, and from the dutiful to the almost liberating. Some feel weighed down or crushed by debt, others feel the pressure both to acquire and pay off certain sorts of loan, and still others embrace credit as a means of asset accumulation and mobility. These classification situations are not merely approximations to pre-existing social groups, though of course they may overlap substantially in specific cases. Rather, they are independently, even "artificially" generated classifications that can come to have distinctive and consequential class-like effects on life-chances and social identities.

\section{The crucible of class}

\section{The standard view}

We begin with Weber and his concept of life chances. It is worth quoting his definition of "economic class" at length:

We may speak of a "class" when (1) a number of people have in common a specific causal component of their life chances (...). This is "class situation." (...) Property or "lack of property" [are] the basic categories of all class situations. ... Within these categories, however, class situations are further differentiated: on the one hand, according to the kind of property that is usable for returns; and, on the other hand, according to the kinds of services that can be offered in the market. Class situation is, in this sense, ultimately market situation (Weber, 1978a, pp. 927-928, emphasis added).

Notoriously, Weber was not very specific about what he meant by "chance in the market." However, he does offer a telling empirical illustration. Rather than pursuing the more Marxist line of analysis he begins with (the distribution of material property and skills or "services offered"), Weber ends the passage on "economic classes" in Economy and Society with a cryptic reference to the credit market:

The creditor-debtor relation becomes the basis of "class situation" first in the cities, where a "credit market", however primitive, with rates of interest increasing according to the extent of dearth and factual monopolization of lending in the hands of a plutocracy could develop. (Weber, 1978a, p. 928) 
This suggests that Weber's view of class situation as life chances in a market should be much more broadly applied than it typically has been in the literature on class analysis. (And, quite possibly, more broadly than Weber himself envisioned-but our purposes here are not exegetical.) Our claim is that many institutional settings may be analyzed as systems of market-situations, each with its own dynamic of social stratification and its own claim on the making of social class.

The standard picture in stratification research is that a person's life-chances are rooted in their position in the occupational structure, and expressed in their pathway through it. One's occupation (or that of one's parents) may affect one's health, the likelihood of arrest or prison, the availability of educational opportunities, and so on. Often, the model is made more complex by the addition of alternative bases of stratification, such as racial, ethnic, gender, religion, age or family structure.

In Weber's view what ultimately determines one's life chances-one's specific market-situation-are individual endowments of various kinds. We would now think of these endowments as various sorts of capital. People own (or do not own) different sorts of property, they bring different skills (or no skills) to the market, they buy and sell various services (or not). It is this individualizing tendency in Weber's theory of stratification-its tendency to unravel class into a set of individual locations on a spectrum-that has long been resisted by his Marxian critics.

\section{From class situation to classification situation}

What is missing from this view is the notion that allocation to particular market-situations might depend on some formal, institutionalized classification procedures. Weber recognizes the power and significance of bureaucratic records and rules, but does not connect this to his analysis of the market. In Weber's time, insofar as this organizational means was available at all, it was almost exclusively a tool of the state bureaucracy. Scholars interested in the intersection of rationalized bureaucracy and logics of classification have thus looked primarily to the state and its official classifications, which are public in nature and carry implications for government policy, identity-formation, and collective action (Hacking, 1986; Loveman, 2013; Schor, 2009; Starr, 1992; Steensland, 2010). But many important classificatory systems are now embedded in markets. They are by nature private, even to the point of being trade secrets. They are oriented toward the extraction of profit and often manufactured and managed in a quasi-monopolistic manner. For instance one company, FICO-originally Fair, Isaac and Company-produces many variants of its FICO score, which it claims are used in ninety percent of lending decisions in the United States. Combining the fine-grain of Weberian market-situations with rationalized organizational methods, these forms of commensuration and categorization have institutionalized and diffused rapidly. As such, they have become powerful "market devices" whose broader social effects are still not well understood (Carruthers, 2013; Muniesa, Millo, \& Callon, 2007). To emphasize our modification of the Weberian framework, we call the outcomes produced by these new technologies classification situations, as distinct from class situations.

The starting point for our analysis is thus the operation of market institutions, not the $a$ priori identification of fundamental social categories. In that respect our perspective contrasts not only with theories of inequality centered on labor-markets, but also with approaches emphasizing the intersectional consequences of cross-cutting memberships in racial, class, and gender categories (Collins, 1990; Massey, 2008; Tilly, 1999). Second, by paying attention to explicit, "objective" classificatory techniques rather than implicit, "subjective" schemes of perception and action, our approach also differs from Pierre Bourdieu's analysis of the relevance of classificatory struggles to class analysis in the last chapter of Distinction (1984). In our case, the classificatory mechanism is both more palpable (classifications are bought and sold) and less so (the mechanics of classification is impersonal, confidential, and does not allow for individual interpretation).

Rather than seeing how basic social-categorical differences "play out", are "expressed in", or "distort" institutions, we thus seek to identify, in a manner not unlike Bowker and Star (2000), how institutions systematically sort and slot people into new types of categories (which we may call "market categories") with different economic rewards or punishments attached to them. On this view, the labor market is only one among many institutions that structure life chances. Education, health-care, credit, and commodity markets classify their participants too, in ways that generate social inequalities rather than simply reproducing them. We also expect configurations of classificatory institutions in different societies to display similarities and complementarities among themselves (DiMaggio \& Powell, 1983; Hall \& Soskice, 2001). This means we must attend to the systemic linkages between classificatory mechanisms, institutional development, and the wider social environment.

We argue that dramatic changes in market organization, triggered by the de-collectivization of social services and risk in the neoliberal era (Hacker, 2008), have both expanded the supply of services and increased the classifying activities of institutions. Both credit and higher education, for instance, provide good illustrations of these trends with a rapid expansion of access (reversed only very recently) and a subsequent internal diversification of supply by price and quality. In both cases, providers have learned to tailor their products in specific ways in an effort to maximize rents, transforming the sources and forms of inequality in the process.

Substantively, the approach we advocate here has three main implications. Comparatively, we should investigate the role of actuarial technologies (Mikes, 2009; Power, 2011 ) in sorting people into a diversified set of life trajectories. In this article, we focus on the U.S. credit market as a useful and important empirical site for studying how these new, "classificatory," mechanisms of social stratification operate. But it is worth emphasizing, again, that the point applies much more broadly. These technologies may be less salient or differently implemented in some countries, 
and thus their effects on stratification may varym too. Historically, we should document how the neoliberal shift transformed institutions-in our case, institutions devoted to the provision of consumer credit-in ways that facilitated the action of classificatory engines. Behind the longitudinal inquiry is the argument that recent changes in the organization of many markets have affected people's lives in ways that are often not well captured by traditional analyses. And theoretically, we ought to reflect on what these changes mean for theories of stratification in the neoliberal era.

\section{Kinds of classification situations}

There have been two historical forces behind the development of classification situations. The first is technology, namely the growing availability of individuallevel data, on the one hand, and the development of statistical models of risk on the other. The second is the market economy. As representatives of the collective good, states tend to be politically oriented toward universal mandates. Under state rule, risks were collectivized, socialized, even though the management of such risks became increasingly individualized over time, though not necessarily more differentiated (Bauman, 2000; Burchell, Gordon, \& Miller, 1991). Private corporations, however, are oriented to profit. In an earlier era, some of the risks faced by private credit institutions might have been socialized through cross-subsidization. Money lost administering small loans in poor neighborhoods, for instance, might have been made up by high profits on large loans in richer neighborhoods. More often, however, banks turned away from the most destitute places if they could, leaving behind so-called "banking deserts" (Leyshon \& Thrift, 1995). ${ }^{1}$

The new actuarial technologies have changed all that, allowing capitalist firms to systematically make individual assessments of risk, and to turn those assessments into economic opportunities through sharply differentiated pricing strategies. No wonder, then, that classification situations are especially well-developed in liberal market economies (Hall \& Soskice, 2001), where private markets, rather than states, are the main providers of access to primary goods and services such as healthcare, money, insurance or the law, and education.

\section{Seeing like a market}

Weberian sociologists and Chicago-school economists alike argue that markets are blind to differences in social status. In the former case, the market "knows nothing of honor" (Weber, 1978b, p. 936); in the latter, it is an unbiased engine of preference aggregation. We suggest instead that markets see social differences very well, and thrive on them. Like states, market technologies make societies more “legible", to use Scott's (1999) phrase. Contemporary market institutions, in particular, are inveterate classifiers.

\footnotetext{
1 This prompted legislation, in 1977, to oblige banks to have a presence in poor communities (Community Reinvestment Act).
}

They count, rank, measure, tag, and score on various metrics of varying degrees of sophistication, automation, and opacity. The data collected in these procedures becomes grist for analytical machines devoted to further refining the classification system itself, and the engine for allocating individuals to some tier or group on the basis of that classification.

Fueled by the growing availability of demographic and non-demographic data over the last 30 years or so, classificatory efforts by corporations have concentrated on the production of increasingly fine-grained knowledge about populations of would-be customers. This data is sometimes provided by states (demographic data), sometimes bought from market intermediaries (e.g. purchasing histories, employment and medical data, records of online behavior, credit scores), or generated by specialists (various forms of market research). This knowledge is incorporated into all kinds of actions, from decisions about the location of shopping outlets to product segmentation to marketing tactics to pricing strategies. Social scientists have been keen to notice the new forms of calculability, governmentality and moral regulation embedded in these techniques. But they have stopped short of examining their broader social implications.

\section{Boundary classifications}

Market institutions produce two main kinds of classification situations. The first distinguishes people who are "in" from those who are "out." For instance, people may be qualified to open a bank account-or be denied the ability to do so; buy health or car insurance-or not; have access to credit-or not. Let us refer to this type of situation, quite simply, as "exclusion" or boundary classification. In much of the world, simple lack of access to goods and services, whether provided by the state or the market, is of course the dominant form of consumption-based classification. It is most obvious where supporting institutions are absent or substandard, as they often are in the developing world.

Boundary classifications can be collective or individual. A good example of collective boundary classifications is the once widespread practice of redlining. Redlining excludes entire neighborhoods from services on the basis of some undesirable social characteristic, usually race. Such collective forms of exclusion, obviously structured by long histories of institutionally-supported racial segregation, ${ }^{2}$ are now formally outlawed as discriminatory. ${ }^{3}$ But their effects are still being felt in the form of reversed patterns of geographical location of bank branches and "predatory" lenders in white and black neighborhoods (Graves, 2003), in African-Americans' weaker personal ties to mainstream financial institutions, and in the persistence of more

\footnotetext{
2 The Federal Housing Authority aggressively promoted the use of racial categories in mortgage finance and home building from its inception up until the 1970s (Freund, 2010).

${ }^{3}$ In the United States, for instance, redlining on the basis race, color, religion, national origin, sex, handicap, or familial status has been illegal in housing since 1968 (Fair Housing Act), credit lending since 1974 (Equal Credit Opportunity Act), and banking since 1977 (Community Reinvestment Act). It arguably survives in insurance.
} 
insidious, but pervasive, forms of reluctance to lend to African-American individuals and communities (Oliver \& Shapiro, 2006).

Modern boundaries tend to be drawn individually, for legal as well as technological reasons. For economists, institutions classifying at the boundary address the problem of adverse selection. In a situation of uncertain information, they separate cases that are "presumed good" from those that are "presumed bad"-the smart from the dull, healthy from unhealthy, lazy from hardworking, prudent from spendthrift. These categories may sound clean and clear-cut, but sorting people is a messy business in practice. In earlier times, the bank or retail finance officers who carried out the work of assessing the creditworthiness of individuals relied primarily on personal judgment. They met potential clients in person, and evaluated them based partly on their physical appearance, their demeanor, and their conversation. They encouraged and listened to local gossip. And thus lending decisions were typically grounded in the agents' opinions and their practical experience with various "social types" and the assumed personal morality of various classes of customers. With the growth of these businesses and the accumulation of payment records by companies, the process became more quantitative. The first credit reporting companies had emerged in the 19th century, collecting rough information about companies (and then individuals), and using it to place borrowers within a standardized, ordinal classification scheme for the convenience of lenders (Carruthers \& Cohen, 2010; Ruef \& Patterson, 2009). By the 1950s, credit rating moved to probabilistic predictions based on statistical analyses of historical population data. But large quantities of non-financial personal information continued to be incorporated, such as marriages, promotions, and arrests (Furletti, 2002). In the 1970s, with financial institutions and retailers now routinely reporting their lending activities, U.S. government institutions endorsed credit scoring-the numerical evaluation of a person's reliability and integrity based on his or her individual credit file-as a neutral, objective way of assessing creditworthiness that would promote fairness in credit markets and eliminate race-based discrimination (Marron, 2009). The new forms of classification were thus based on data about individual rather than group credit histories; they included provisions that made the collection and use of certain demographic data illegal; and they were impersonally administered. ${ }^{4}$

Market classifications are part of a general movement toward the institutionalization of "mechanized objectivity" (Porter, 1995). Because they increase trust (Guseva \& Rona-Tas, 2001) and efficiency, there is ample evidence that these new techniques have increased equality ex ante by broadening formal access to the financial system and

\footnotetext{
4 The Equal Credit Opportunity Act of 1974 makes it unlawful to discriminate applicants on the basis of the following categories: age, marital status, race, color, religion, national origin, receipt of public assistance, and good faith exercise of any Consumer Credit Protection Act right (Hsia, 1978). In spite of these legal precautions, practices that are on face value-neutral may still have a disparate impact across populations because the characteristics recorded by scoring systems are not evenly distributed across subpopulations (Cohen-Cole, 2011; FRB, 2007).
}

shrinking the percentage of people excluded from services. ${ }^{5}$ Carefully graded assessments could now balance heightened risk with higher prices, and so the new classification technologies fueled a huge expansion of products specifically marketed to traditionally disadvantaged (and excluded) categories of people. ${ }^{6}$

The shifting boundary: the expansion of credit in the United States

The rise of credit scoring systems can also be seen as part of a long trend towards the expansion of access to formal credit and the financial system more generally. As Cooper and Sherer put it, "any accounting contains a representation of a specific social and political context" (1984, p. 208). In the twentieth century, American policy elites generally regarded market exclusion, or lack of access to conventional market institutions, as both unfair and inefficient. Since the Progressive period, reformers of all stripes in the United States saw the expansion of mainstream credit access as a requirement of a well-functioning economic democracy. They also supported the moral argument that people ought to be protected from exploitative financial dealings. During the interwar period, for instance, experts from the Russell Sage Foundation actively and successfully mobilized to reform and develop the small loan industry (Anderson, 2008; Carruthers, Guinnane, \& Lee, 2012). They reasoned that raising legal interest rates just slightly above usury law levels would attract mainstream lenders to the small loans business and drive out illegal predatory lenders. By the late 1930s, most states had followed their recommendation. ${ }^{7}$

In addition to these private efforts, federal agencies also endorsed the "democratization" of credit. Expanding access became an explicit policy goal toward the end of the Great Depression, and from then on successive generations of policy makers embraced it as a means to accelerate social mobility, and, increasingly, generate economic growth (Quinn, 2011). One of the most significant factors in the more recent development of the US credit market was a 1978 Supreme Court decision (Marquette National Bank of Minneapolis $v$. First of Omaha Service Corporation) ruling that state anti-usury laws regulating interest rates cannot be enforced against nationally-chartered banks based in other states. The Marquette decision caused national banks to relocate to states with the most lenient usury laws. This

\footnotetext{
5 Nevertheless, scoring has been shown to result in significant disadvantages for certain categories of the population. Minorities are more likely to be excluded from credit altogether, or to receive worse treatment than their white counterparts, net of other differences (FRB, 2007). As Marron (2007, p. 111) puts it, "scoring undercuts the coherent identity of being "female" or "black" within which oppression or marginalization is experienced, displacing credit decisions onto an array of discrete characteristics or attributes seemingly innocent within themselves and seemingly individually predictive of repayment performance, independent of subjective will."

6 See Mian and Sufi (2009) on the mortgage market. They find considerable evidence that mortgages were actively marketed in subprime ZIP codes between 2002 and 2005, despite sharply declining relative income growth in those areas. See also Fligstein and Goldstein (2010).

7 Note that a very similar logic played out to legitimize micro-lending in the developing world. See, e.g., Roy (2010).
} 
fueled a competitive race among states to attract banking business, which resulted in a weakening of usury regulation and surveillance across the country (Langley, 2009, p. 145; Sherman, 2009). Further deregulation in the 1980s (such as the phasing out of Regulation Q) again increased competition among financial institutions, contributing to the Savings \& Loan collapse, and to a wave of mergers and consolidation in the banking sector (Krippner, 2012).

What effects did these changes have on the relationship of households to the banking system? The data for this period is complex, and at times contradictory, but two trends are clear. Since the late 1980s there has been increased inclusion at the boundary, and increased segmentation within the market. The percentage of U.S. households with a transaction account has increased significantly over the last three decades, particularly among the most socially disadvantaged categories of households (from $85 \%$ to $92 \%$ of all households between 1989 and 2007, but from 56\% to $75 \%$ of households in the bottom quintile of the income distribution). ${ }^{8}$ Having a checking account is hardly equivalent to the democratization of access to credit, of course. In fact, the new banking inclusion notwithstanding, the percentage of people who report having difficulty accessing regular credit has also grown since the mid-1980s in practically every social category except the most privileged.

So how was the unfulfilled desire for credit met? Framing the problem as if everyday borrowing had "a clear and unambiguous inclusive side, on the one hand, and an excluded outside, on the other" misses a big part of the picture (Langley, 2009, p. 168). Instead of the inclusive expansion of credit for the poor envisaged by early credit reformers, a new landscape has developed at the bottom end of the income scale, which is marked by a blurring of boundaries between mainstream and fringe lenders. In particular, access to formal banking has set the stage for the rapid growth of payday lending (a form of salary advance), which-unlike earlier forms of marginal credit, such as pawning-requires the borrower have a bank account (Caskey, 1994).

The rapid and largely unfettered expansion of payday lending, of other expensive small scale credit providers, and of high fee credit services offered by banks did not take place in a political vacuum. It reflects, in part, the growing reliance of American political authorities on individual responsibility against top-down regulation in moralizing markets. In the consumers' republic that flourished in the postwar period, protecting people from abuses by fettering markets ex ante was perceived as political and economic suicide, given prevailing ideologies and the fact that domestic consumption drove over two-thirds of the national economic machine. ${ }^{9}$ Instead, better information and disclosure rules, as laid out in the Fair Credit Reporting Act of 1970 or in the Equal Credit Opportunity Act of 1974, were trusted to guard presumably rational consumers against the deceptive and high cost business practices that inevitably arose in this expanding market. These policies gained the

\footnotetext{
8 Federal Reserve Board, Survey of Consumer Finances, 1989-2010.

9 Data from the World Bank (Household consumption as a percentage of GDP).
}

upper hand in spite of numerous studies and repeated congressional hearings documenting the low levels of financial literacy among the US population, particularly the poor and minorities (Lusardi \& Tufano, 2009). ${ }^{10}$ Unsurprisingly, the effect of these changes on equality has been much more questionable than promised. Inequities in the market are thus now "less a matter of access to credit and abandonment, and more a matter of the differential interest rates that borrowers pay to lenders across both mainstream and alternative networks of borrowing" (Langley, 2009, p. 168). By enabling and facilitating the differential pricing of people, scoring has expanded the reach of the market while opening the door to new forms of classification with powerful stratifying effects. The market expands at the boundary and then differentiates internally. We now turn to the latter process.

\section{Within-market classifications}

"Individuals viewed through statistics no longer need to be classified as either 'in' or 'out' of the market. Armed with a gradated sliding scale, people all along a spectrum of risk can be offered specially designed products at alternative terms and prices" (Poon, 2009, p. 167).

These new forms are within-market classifications. Rather than dividing people into two mutually exclusive groups, the new devices position them in a categorical framework or on a continuous scale, the latter usually having key cut-points or thresholds. Categories and thresholds restrict access to certain goods and services, specify their price, or both. Within-market classifications are very widespread, reaching ever more broadly across spheres of life and ever deeper into population segments. Companies keep records on their customers' purchasing behavior (or buy these from other firms), thus enhancing the pertinence and power of marketing and data collection. From an economic point of view this is the problem of managing moral hazard. The classifying institutions are meant to be performative. They steer behavior toward some desirable goal, and encourage people to stay on top of their commitments. There are incentives for compliance, material or symbolic rewards for success, and sanctions for failure. Rewards and punishments are often themselves acts of reclassification. Punitive reclassification, for instance, may entail higher premiums, loss of privileges, poorer service, or higher interest rates.

Much of the regulation in neoliberal, and, importantly, post-segregation markets must come from within, from self-monitoring subjects: its accounting infrastructure is oriented to the responsible and efficient functioning of “calculating selves" (Cooper \& Sherer, 1984, p. 208; Hopwood, 1994; Miller, 1992; Miller \& O'Leary, 1987). Credit scores in particular have a moral aspect, tracking a person's consumption choices dynamically, and reflecting on his or her evolving moral self. In this world,

\footnotetext{
10 Even face-to-face financial advice meant to teach consumers about the relative risks and benefits of different products is fraught with social tensions. See the very interesting work by Vargha (2011) on Hungary and by Lazarus (2012) on France.
} 
redemption for those who have failed is always available in principle. Only proper self-management is required. This sorting and scoring of people is disciplinary and productive. Its underlying structure and effects are subjectively incorporated. Both the scored and the score-users orient themselves to these measures and strategize about them, in a "reactive" effort to gain control (Espeland \& Sauder, 2007). For instance, fraudulent companies may send a flurry of unnecessary credit inquiries right before negotiating a loan with a customer, because they know an inquiry without a subsequent loan will affect this person's credit score negatively and thus boost the interest rate they can charge. For individuals, there is an advice industry that teaches how to manage (or game) one's credit score, or how to keep fees and premiums low. This knowledge is offered freely or packaged as a product by advocates online and in newspaper articles; by banks, debt consolidation companies, bankruptcy lawyers, consultants, and firms marketing "FICO security toolkits". Other sources of knowledge include government agencies, nonprofit organizations, academics concerned with financial literacy, and more.

Self-monitoring within the system of credit classification has its limits. At the bottom end of the scoring scale are those who either do not have a score (because they do not use the mainstream credit system) or whose score is so low that it only serves to permanently maintain them outside of the system (and is thus less likely give rise to a form of deliberate management). The exclusionary boundary still cuts through the inclusive world of credit scoring in the form of a stubborn stratum of unscorable, unscored, and underscored individuals-a Lumpenscoretariat composed mostly of poor people. In the National Financial Capability Study (FINRA, 2009), 56\% of the people surveyed with incomes above $\$ 75,000$ had obtained a credit report, as compared with $18 \%$ of those with incomes below $\$ 25,000$. Economists typically explain this discrepancy in self-surveillance in terms of disparities in "economic literacy" or, worse, sheer behavioral irrationality (e.g. Bertrand \& Morse, 2011). But what this difference captures, fundamentally, is the objective and subjective marginalization of the less privileged from the world of mainstream credit. Because credit behavior is recorded and interpreted as a sequence of individual choices, the vagaries of harsh circumstance, the power of differentiated markets, and the pressure of social competition-all of which powerfully structure how, where and when people borrow and repay-magically disappear from view.

\section{The three worlds of credit in America}

As is clear from the examples and data we have discussed so far, the institutional machinery for generating classification situations is to be found in its most developed form in the United States. The way the credit-scoring process erases circumstance seems an extraordinary irony in a country where people rely extensively on credit to compensate for the cover over holes in the welfare system (Prasad, 2013). A 2009 Federal Deposit Insurance
Corporation survey of underbanked ${ }^{11}$ consumers in the United States found that 38\% of them relied on highly exploitative "fringe" lenders (payday, for instance) to cover basic expenses, and a further $19 \%$ used them to cover medical expenses, child care expenses, and lost income (FDIC, 2009b, p. 42). For African-Americans especially, the incidence of these services increased markedly with the number of children in the household. ${ }^{12}$

It is the combination of weak social welfare provision and the abundance of variably-priced credit that makes classification situations consequential in liberal market economies. As Prasad (2013, pp. 234-235) remarks, "there is a relationship between credit and the welfare state, such that where we see greater growth in credit we see less growth in the welfare state since the 1980s." Furthermore, "regulation suppresses credit in less well-developed welfare states, while deregulation allows the credit-financed consumption of goods and services that would be provided by the welfare state elsewhere."

Credit scores of the sort calculated by the U.S. credit bureaus are much less common in countries with more developed welfare states. Many have no private credit reporting organizations at all. The information recorded by their public credit registries is extremely limited, and generally confined to identifying seriously delinquent accounts (Miller, 2003). Against the American view of credit as an instrument of individual empowerment, public authorities in France and Germany perceive loans to be threatening and dangerous (Trumbull, 2012). Consequently, interest rate caps and levels of personal indebtedness are much lower, as is the market penetration of credit cards. About nine million personal credit cards circulate in France (about 0.17 per adult), compared to about 75 million in the United Kingdom (about 1.4 per adult) and close to 1.2 billion in the United States (about 5.2 cards per adult). ${ }^{13}$

In the United States, credit has long been seen as a "welfare-enhancing right" (Trumbull, 2012). Earlier models of popular credit had a strong solidaristic basis. The first thrifts were "highly personal nonprofit associations" of "small groups of individuals [cooperating through structured savings] to achieve the common goal of home ownership" (Haveman \& Rao, 1997, pp. 1616-1617). The bureaucratization of thrift in the early part of the twentieth century eroded the culture of personal relations and structured discipline by stressing to voluntary savings schemes. Still, mutual ideologies persisted through the development of credit unions, mutual savings banks, and community development banks. Since the 1970s, however, the normative basis of the case for credit has shifted. While the total number of customers served by mutualistic organizations did not decline substantially, its underlying organization

\footnotetext{
11 In contrast with "unbanked" consumers, who do not have a bank account, the "underbanked" (as defined by the FDIC) have a bank account but rely also on fringe lending to meet their day-to-day credit needs.

12 The incidence of having used a payday lender in the past year, for instance, varied from $7 \%$ for African-American households with one child to 14\% for households with four children (FDIC, 2009a).

13 Source: US Census Bureau, 2012 projections. This is down from a peak of close to 1.5 billion in 2006. See http://www.census.gov/compendia/ statab/2012/tables/12s1188.pdf.
} 
changed. The older patchwork of local financial institutions disappeared. Credit unions gradually consolidated. Mutual savings banks were converted to a stock-ownership model. As the institutional form changed, and as lenders started reaching into new categories of previously excluded people, the moral life of credit changed, too. The idea that the poor ought to qualify for more favorable terms because they were poor was gradually replaced by the idea-now almost completely taken-for-granted-that the terms of credit ought to depend solely on one's prior credit-related behavior, as recorded in an increasingly mechanized reporting system. ${ }^{14}$

Credit scores quantify individual performance, determining which services can be obtained, in terms of type (home equity, credit card, or payday loans), volume (how much credit is extended), and price (the interest rate, required origination or balloon payments, and other fees). ${ }^{15}$ For instance, here is a crude but honest recommendation from the British industry publication The Banker: "Stop trying to lend at low margin to accountants, lawyers and civil servants who are reliable but earn the bank peanuts. Instead, find the customers who used to be turned away; by using modern techniques, in credit scoring and securitization, they can be transformed into profitable business" (Langley, 2009, p. 473). The modern credit enterprise relies on the systematic measurement and exploitation of social differences, by way of scoring systems. The flipside of market inclusion has been an acceleration of market segmentation. Populations have been incorporated and then matched to tailored industries and products. As a result, credit functions differently and is experienced differently across positions in the social structure.

\section{The perils of exploitation: weighed down by necessity}

The normalization of high-interest credit products is one of the distinctive features of the relatively weakly regulated American credit economy that the United States represent. Fueled by the post-Marquette regulatory environment at the national level and the gutting of usury laws at the state level, the widespread diffusion of "subprime" loans and the flourishing of the so-called "fringe" banking economy transformed the credit environment among borrowers with low to moderate credit scores. The discrepancy between the interest rates paid by high credit-score borrowers and low credit-score borrowers has enormously increased since the late 1980s across all major product types, such as mortgages, car loans, and consumer loans (Grow \& Epstein, 2007).

This trend was facilitated by the increased visibility of those on the low end of the social scale. They became better incorporated into the banking system but remained poorly served by it, with high barriers of entry into savings and investment products (Schneider \& Tufano, 2007) and continued difficulties in securing credit. The implied market opportunity was not lost on the most dynamic parts of the fringe-banking industry. As states relaxed laws

\footnotetext{
14 We are grateful to Eve Chiappello for helping us articulate this point.

15 For details on scoring technologies see Leyshon and Thrift (1999), Marron (2007) and Poon (2007).
}

against high-cost, short-term borrowing, reputable, professional, rationalized market actors replaced the loan sharks of yesteryear. So-called "alternative financial services" (AFS) have grown rapidly in the United States and other liberal market economies, expanding and diversifying the supply of legitimate credit for previously excluded categories of people while also increasing its cost. For instance, the number of payday loan storefronts in the United States rose by an order of magnitude between 1996 and 2007, from 2000 stores to $23,600 .^{16}$ Lending in anticipation of tax refunds, which grew out of the tax preparation business, has also flourished. The Jackson Hewitt Corporation, which pioneered these expensive short-term loans in advance of expected tax refunds, saw business grow from about 900 storefronts in 1993 to 6,000 in 2011. Not unlike the loan sharks they replaced, lenders of this kind remain relatively vulnerable to shifting political moods. In the midst of the recession, AFS services have become easy targets of legislative and popular anger-see for instance changes in IRS regulations, ${ }^{17}$ or recent state and federal actions against payday lenders, which have resulted in a sharp decline in the number of stores since the 2007 peak. ${ }^{18}$ But this decline masks a shift toward online lending and more mainstream financial services. Indeed, payday lending's business model has been so successful that banks (whose action was initially confined to bankrolling the AFS industry) have adopted it, too. Many now offer "bank payday" services, as well as other feeloaded services marketed under the label of consumer convenience. $^{19}$

The eighteen percent of the US population the FDIC (2009a) defines as "underbanked" are banked in the mainstream but loaned to in the fringe. What critics call economic predation is routine at the low end of the creditscoring scale. This overlaps greatly, though not perfectly, with the bottom end of the income scale, and even more with the racially or ethnically dominated segments of the social structure. ${ }^{20}$ Loans from payday lenders typically carry annualized interest rates above $400 \%$, and up in the $700 \%$ range in some locations, and rollovers (which extend the fees generated by the initial loan) are not only extremely common but an essential component of the industry's business model. ${ }^{21}$ At first glance, this situation seems to vindicate Marx's grim assessment of usury in Volume III of Capital. There he critiques high-interest lending as a "subordinate" (i.e. derivative) form of exploitation "which runs parallel to the primary exploitation taking place in the production process itself." As part of the financial system, usury

\footnotetext{
16 For comparison, there were approximately 11,000 Starbucks coffee shops and 14,000 McDonalds restaurants in the United States at the end of 2007.

17 RALs (refund anticipation loans) are a by-product of an IRS decision to release to financial companies a "debt indicator" flagging loan applicants owing back taxes. The IRS release was suspended in 1994 (but reinstated shortly thereafter), and again in 2011, effectively condemning the industry.

18 In 2007, a federal law capped lending to military personnel to 36\% APR.

19 Automatic overdraft protections are an example.

20 The proportion of Americans who resort to alternative financial services at least once a year is highest (24\%) for people making less than $\$ 50,000 /$ year

21 In the United States, rollovers of payday loans are actively encouraged by lenders. Their bottom line often depends on chronic borrowing (Stegman \& Faris, 2003).
} 
preys on productive labor in a parasitic fashion: "Usury, just like trade, exploits a given mode of production, but does not create it; both relate to the mode of production from outside" (Marx, 1981, p. 745). But-focused as he was on the intersection of money lending and capital accumulationMarx also believed that usury was not particularly discriminating. It ruined rich estate owners and small producers alike, dissolving all forms of property and productive capital in the acid-bath of debt.

Marx was too optimistic. He did not anticipate how a modern, credit-driven, consumer economy could weigh so heavily on workers' incomes. Nor could he have predicted how the analytical tools of credit scoring would come to differentiate the form and price of credit so effectively, even for those at the bottom of the market. The net result, as Harvey (2007) has argued, is that the consumer credit industry is characterized at the bottom-end by forms of material dispossession and subjective alienation similar to those Marx described in the world of production. Soederberg (2012, p. 495) describes this form of accumulation, where "a maximum amount of workers take on the greatest amount of debt at the highest interest rates and fees possible to extract ever higher rates of revenue streams", as "cannibalistic capitalism."

Those who are offered rotten terms in the market because they are riskier prospects are more likely to remain so when the terms on offer are rotten to begin with. Economists have shown that the use of fringe banking services traps people into cycles of debt, leading to higher rates of bankruptcy and foreclosure (Melzer, 2011; Skiba \& Tobacman, 2009). These cycles also exact a high personal and social toll, leading to higher rates of anxiety, divorce, or forced geographical mobility.

For those individuals and households, the new regime does not so much teach financial self-control as resign them to the seemingly inevitable. People who live paycheck-to-paycheck-or without a paycheck-are rarely in a position to plan systematically (Conley, 1999). Perversely, means-tested social programs may "actively discourage low-income families from accumulating cash in bank accounts ... lest they lose access to needed programs" (Newman \& Chen, 2007, p. 210). The lesson repeated over and over is that the extremely harsh economic conditions they face are a kind of natural market law. After all, the interest rates on their small loans-on the order of thirty percent per month-are objectively and legitimately tailored "for them" (Marron, 2009, p. 151). In the United States, large differences by race and ethnicity (but also income) in the probability of denied and discouraged applications still persist, so minorities are simply much more likely to not apply for credit for fear of being rejected (Weller, 2009). As Sudhir Venkatesh's ethnographic material vividly illustrates, the "prevailing wisdom [among African Americans] is that loan applications will be rejected. K.C., the co-owner of a Laundromat, puts it succinctly when he says, 'We all try, time to time, to get to a bank, but a dog just don't want to go back if all they do is get beat. I guess we need a year or so to forget that last beating, and then maybe we'll go back. But most of us can't get no money. Shit, I wouldn't lend myself no money, knowing what kind of credit I got and how much I owe"" (Venkatesh, 2008, p. 121). In other words, the exploitative credit regime is successful precisely because it is subjectively made sense of and incorporated, to some extent, as "normal."

Race features prominently in this moral compact. In focus group interviews conducted by the Center for Responsible Lending in 2010, ${ }^{22}$ African-American users of fringe banking services generally expressed broader support for a system that, they said, is there for them when no one else is: it is "just so hard to get anything from the banks." Some even expressed sympathy for lenders who, after all, "are a business and [are] out to make money." One interviewee remarked: "I do think [payday lending] is fair because you go in there knowing. You know what you need; you know what you're going to pay. They're taking a risk. They're not doing credit checks." Payday lenders were often preferred to banks for their comfort, the convenience of their hours of operation and location, and the accommodating stance of their staff (bank employees, by contrast, could be "straight rude").

Racial differences in attitudes toward payday lending must be read against the long history of African-American exclusion and exploitation by lenders of all types. The objective experience of being rebuffed by mainstream credit providers, the expectation of paying more for similar services, and patterns of geographical proximity and distance all may sustain a set of specific subjective dispositions-in particular, greater mistrust toward banks, and a more benign attitude toward alternative financial providers. As Pierre Bourdieu (1984, p. 372) pointed out in a different context, "necessity imposes a taste for necessity which implies a form of adaptation to and consequently an acceptance of the necessary, a resignation to the inevitable, a deep-seated disposition which is in no way incompatible with a revolutionary intention..." Thus, while ambivalence towards an exploitative institution was not absent ("[payday loans] can cripple you"), Blacks were more likely to see payday lending as a necessary and socially useful evil, affording them more dignity than other types of financial help, such as relying on charity or welfare. Financial exclusion tended to foster the conditions of its own acceptance.

Meanwhile, in the same study, White intervieweeswhose access to mainstream credit has long been objectively better and subjectively much more self-evidentsaw their own reliance on fringe services, which often resulted from the closing of alternative mainstream possibilities, as an unfair downfall into a deeply repugnant system not made for them. They expressed a much greater rejection of the business, talking about "loans from hell", and likening the practice of borrowing from payday lenders to "selling blood" and to "slavery." But of course they were also more likely to have an easier time finding alternative sources of credit.

\footnotetext{
22 Cited with permission from the Center for Responsible Lending. Focus group interviews were broken down by race/ethnicity: Spanish language, Anglo and African-American.
} 
The difficulty of measuring up: economic goodwill and suffering

The disciplining effect of credit scores is perhaps most evident in the middle sections of the social scale. It is there that we find the most articulated forms of what, paraphrasing Bourdieu's (2005) analysis of the middle-class lifestyle, we can call economic "goodwill". This is a distinctive combination of striving and straitening, desire and self-denial, hedonism and frustration. Here credit use expands and diversifies. The number of credit cards in a household, for instance, rises continuously with income. Borrowers-often heeding the advice of popular financial gurus-use borrowing as an active strategy for asset-building. And it is here, too, that credit scores matter the most. At the bottom, scores are often a blind spot, or a lost cause. At the very top, they are a natural gift, an afterthought, or a taken-for-granted personal quality.

At the bottom of the middle class, the story is one of "middle class squeeze" (Wolff, 2010) fueled by the admixture of oversupplied credit and stagnant real incomes. This market segment is where one finds the riskiest mortgage products, as grand aspirations and limited means are brokered into an unhealthy marriage. In the United States, these products are targeted towards non-white populations, as well as to the least educated. The foreclosed upon, who had to be wealthy enough to obtain a mortgage, and the bankrupt, for whom mortgages were a major cause of bankruptcy, largely come from there. ${ }^{23}$ Thus in their 1983 survey, Sullivan, Westbrook and Warren (1999, p.331) found that personal bankruptcy is, by and large, an "ordinary story of middle-class people drowning in debt". ${ }^{24}$ But it is worth noting that the upper reaches of the middle class are drowning in debt, too. The exponential wealth accumulation and income gains among the top quintile drove an endless competition over lifestyle and a rapid increase in the price of assets. Those lower down in the income distribution did not do nearly so well. In the fourth quintile of the income distribution, income gains since the late 1970s were essentially nil. Those in the third quintile saw their incomes decline in real terms. Consumers in these segments borrowed more at less profitable terms, and leveraged their assets aggressivelyusually with home equity loans-trying to keep up. It is in these sections of American society that one finds the highest debt/net worth and debt/income ratios (Wolff, 2012, 2010). ${ }^{25}$

In his analysis of the mortgage market, Bourdieu describes the middle-class experience of credit as an example of "petit-bourgeois suffering". "By embarking upon projects that are often too large for them, because they are

\footnotetext{
23 Almost 40\% of the foreclosed upon and seriously delinquent mortgages come from borrowers whose income is well above the median income of the area (Gruenstein Bocian, Li, Reid, \& Quercia, 2012).

24 However, the incidence of bankruptcy has moved noticeably down the income scale since then. See Sullivan, Warren, and Westbrook (2006).

25 Over the last 20 years in the United States, debt-to income ratios have been highest in the third and fourth quintile of the income distribution (Source: Federal Reserve Board, Survey of Consumer Finances). In 2007, these ratios reached respectively $155.4 \%$ for the fourth quintile and $130.7 \%$ for the third quintile. In the same year the debt-to-income ratios of the bottom 40\% households were “well below 100\%” (Weller, 2012).
}

measured against their aspirations rather than their possibilities, [the middle classes] lock themselves into impossible constraints, with no option but to cope with the consequences of their decisions, at an extraordinary cost in tensions, and, at the same time, to strive to content themselves, as the expression goes, with the judgment reality has passed on their expectations" (Bourdieu, 2005, p. 186). We prefer the term "middle class" to the more archaic "petite bourgeoisie." But Bourdieu puts his finger on the specific structural constraints faced by this group, which are at the root of its contradictory ethos of discipline and self-gratification. The middle class is squeezed between the "morality of saving" and the "morality of credit" (Bourdieu, Boltanski, \& Chamboredon, 1963). Meanwhile, Daniel Bell (1996) also saw the unstable fusion of hedonistic indulgence with agonized but morally consistent middleclass Protestant striving as the central cultural tension in modern American capitalism. ${ }^{26}$ This contradiction is perhaps nowhere as clearer than in credit institutions and personal bankruptcy laws that are at once punitive and redemptive (Skeel, 2001).

In a world of scores rather than classes, economic technologies transform this dilemma. On the one hand, they objectify the material constraint by expanding consumer aspirations and the possibility of "keeping up with the Joneses", albeit at differentiated prices and levels of vulnerability. But they also reinforce the practice of selfsurveillance. People can, in principle, take the measure of their constantly changing position on the FICO scale. First, the old-fashioned face-to-face interaction between bank officers and clients-what Lazarus (2012) calls the test, or the trial, of credit (l'épreuve du crédit)-is now routinized, invisible and depersonalized, but also multiplied and repeated with every credit check. Second, with behavioral scoring, one's credit possibilities are a constantly moving target, readjusted with every activity. One's credit identity thus becomes a dynamic project to be managed through an "ethic of improvement" (Marron, 2009, p. 193), and in a manner all the more insatiable because good credit is seemingly within everyone's reach. Hence the multiplication of financial education programs (often state-sponsored), TV shows and pedagogical devices, in the US as elsewhere (Bay, 2011; Fridman, 2010). No wonder, then, that this is also where activity around the score intensifies rapidly. Our analysis of FINRA data shows that the likelihood of checking one's credit score or obtaining a credit report rises sharply with income and education, and only tapers off for households with incomes above $\$ 150,000$ per annum, and for people with advanced degrees (see FINRA, 2009).

\section{The benefits of appreciation: virtue and privilege at the top}

The top of the credit scoring scale overlaps in part with the top of the income and net worth scales, but even more closely with the top of the education scale (Lusardi, 2011). The main virtue of the very high earners, from the point of

\footnotetext{
${ }^{26}$ In a phrase that now sounds even more archaic than "petite bourgeoisie", Daniel Bell called this the problem of demanding that people be "straight by day and swingers by night" (Bell, 1996, p. xxv).
} 
view of algorithms, is that they are just less likely to overburden themselves with debt, or have difficulty managing payments. But the most "responsible" consumers also tend to be highly educated. They are best equipped with the cultural capital to navigate the business of credit and credit scoring. "Over all, those with the highest scores keep low revolving balances relative to their available credit; they don't "max out" their credit cards; and they consistently make payments on time, even if it's just the minimum required amount" (Carrns, 2012). And thus credit providers compete fiercely to attract those people who borrow large in absolute terms but repay in a predictable and controlled way-mostly because they have the means to do so. And so additional benefits pile up, too, implicitly subsidized by the structure below.

Whether it is earned or a byproduct of abundance, economic virtue generally brings material rewards. But the multipliers effects of an excellent score kick in even more strongly in the higher income and wealth brackets. Those who find themselves in this position can leverage their assets via the credit system to accumulate more at a cheaper cost. This is especially true when the value of those assets rises quickly, as it did during the 1990s and most of the 2000s. Through the financial system, they can also invest, make money work for them through stock ownership, rental properties or home ownership in desirable locations, and perhaps even live "by collecting interest" (Graeber, 2010, p. 388).

There are symbolic rewards, too. Those who think that market institutions are inevitably erase distinctions should attend to the astonishing prevalence of "private," "exclusive," or "elite" categories of membership across consumer markets of all kinds. Consumers who belong to the right categories-customers who are silver, gold, or platinumplated-get special treatment, better service, and all kinds of side material benefits. ${ }^{27}$ Their position appreciates, so to speak, because the system appreciates their position. Far from eliminating exclusionary status distinctions, market society proliferates them. The key difference is that these honors and rewards are not bestowed by accident of birth or via some sumptuary law. Instead, bureaucratic systems track behaviors, record progress through the classification system, and rationally assess when particular cases will be elevated-or downgraded-to a new status.

In this social stratum, the intertwining of material and symbolic benefits not only creates a sense of comfort around credit, it also fosters a sense of privilege, and encourages a proactive attitude toward providers. In our analysis of FINRA data, we find that these are the people who shop around, refinance, rebalance their accounts frequently, and pay back their loans in advance. In periods of tight money, when the competition for customers with good credit intensifies, they are also the ones who benefit the most from government actions designed to ease the crunch. Thus a Wall Street Journal article reported that cash

\footnotetext{
27 For instance, various forms of insurance for their purchases. Or take the singling out of elite customers at the airport: first to enter and leave the plane, they have access to special areas (lounges, gates, parking spaces), and their names magically appear on the "cleared list" while the hoi polloi are rebooked.
}

injections by the Federal Reserve in the aftermath of the 2008 credit crunch have almost exclusively benefited the most creditworthy, because banks would only lend to people in the higher-scoring brackets (e.g., above 700): “"even though we have the greatest monetary policy stimulus in the history of the Fed, we really have not managed to lower the funding costs for a large swath of people,' said David Zervos, a bond strategist with Jefferies Inc., a Wall Street investment bank. He called Fed efforts 'monetary policy for rich people"' (Hilsenrath, 2012).

\section{Conclusion}

"It is easy to understand how the power of the norm functions within a system of formal equality, since within a homogeneity that is the rule, the norm introduces ... all the shading of individual differences." (Foucault, 2012, p. 184)

Much of the theoretical debate on stratification in the twentieth century orbited around three attractors: big classes grounded in exploitative labor relations, individual returns to human capital or skill in the market, and occupational-level social closure, often built on some categorical identity. We propose to revisit class analysis in the light of techno-social changes generated by the advent of novel market devices. These devices segment, score, classify and target concrete individuals in increasingly precise ways, in a world where profits depend on exploiting these techniques effectively. We argue that understanding how classification situations are produced through the operation of scoring, segmenting and marketing instruments is essential to understanding the structure of new class situations, when class is conceived as the social distribution of life chances in markets.

Credit scores commensurate people, classify and rank them (Espeland \& Stevens, 1998). Scores are attached to variable economic rewards (such as different interest rates), and are part of the process by which shared market-situations are generated. This process is strengthened the more credit scores are routinely incorporated as assessment and screening devices in other markets, such as insurance, employment, real-estate-even dating (FTC, 2007; Silver-Greenberg, 2012; Wacquant, 2009, p. 139). Credit scores facilitate differential pricing and terms of access to goods and services across a wide range of domains. They are an active, independent force that structures people's life-chances via their financial position-all the more in a society where the median household debt is about double the median annual income-and which, once established, percolates to every aspect of people's lives. ${ }^{28}$

\footnotetext{
28 Of course what is true of credit scores is true of other types of behavioral records, like criminal records or eviction records, which also have a deep effect in structuring life trajectories (Pager, 2007; Desmond, 2012). In a more benign manner, tracked purchase records with stores have transformed the political economy of marketing and selling, with high purchase levels being routinely rewarded with larger discounts and better services.
} 
It is important to remember that while these scoring systems grew up in a social context already highly structured by established inequalities in occupational attainment, education, income, and racial stratification, they do not simply reproduce the status quo ante. Accurately tracked measures of credit-related behavior are far better predictors of outcomes than broad measures of educational attainment or racial classification. (Fourcade \& Healy, 2013) That is one of the reasons lenders use them. Social scientists would use them, too, were they not trade secrets. Their analytical use and active application in markets does more than simply "freeze a certain state of the power relations." (Bourdieu, 1984, p. 482) It recreates these relations anew. If social class is the distribution of bundles of life-chances expressed as market situations, then we need to rethink class analysis through the prism of credit scores and similar devices.

In the 1960s, there was a debate centered on the notion that "the poor pay more" (Caplovitz, 1963). With the Great Society and the expansion of welfare programs, it waned. But its main idea-that being poor costs money, that firms looking to do business with the poor know this, and systematically exploit it-is worth retooling for a neoliberal era. Debt has become more accessible, but also a lot more expensive at the bottom end of the social scale. And now it is not simply the 'poor' that pay more, but much more specific categories of people, measured and targeted by moralized market instruments and differentiated market institutions. Classification situations may have become the engine of modern class situations.

\section{Acknowledgements}

We thank Steven Barley, Irene Bloemraad, Bruce Carruthers, David Cooper, Eve Chiapello, Matthew Desmond, Marie-Laure Djelic, Derek Hoff, Andreas Kalyvas, Daniel Kluttz, Jeanne Lazarus, Roi Livne, Bruno Palier, Alex Roehrkasse, Matthias Thiemann, Loïc Wacquant, Erik Olin Wright, Valery Yakubovich, two anonymous AOS reviewers for helpful comments on an earlier version of this article or insights about its subject. This work was presented at the annual conferences of the American Sociological Association (2011), the Social Science and History Association (2011), the Society for the Advancement of Socio-Economics (2011), the Interdisciplinary Perspectives on Accounting Conference (2012), the "Politics of Markets" conference (Berkeley 2009), the conference on "Economic Modernity in the 21st century" (Barcelona 2012) and the Max-Planck-Sciences Po Center inaugural conference (Paris 2012), as well as in talks at Duke University, ESSEC Business School, Harvard University, Princeton University, Sciences-Po, the University of California Berkeley, the University of Chicago, and the University of Pennsylvania.

\section{References}

Anderson, E. (2008). Experts, ideas, and policy change: The Russell Sage Foundation and small loan reform, 1909-1941. Theory and Society, 37(3), 271-310.

Bauman, Z. (2000). Liquid modernity. Cambridge: Polity Press.
Bay, C. (2011). Framing financial responsibility: An analysis of the limitations of accounting. Critical Perspectives on Accounting, 22(6), 593-607.

Becker, G. S. (1971). The economics of discrimination. University of Chicago Press.

Bell, D. (1996). The cultural contradictions of capitalism. Basic Books.

Bertrand, M., \& Morse, A. (2011). Information disclosure, cognitive biases, and payday borrowing. Journal of Finance, 66(6), 1865-1893.

Bourdieu, P. (1984). Distinction: A social critique of the judgement of taste Harvard University Press.

Bourdieu, P. (2005). The social structures of the economy. Princeton, NJ: Princeton University Press.

Bourdieu, P., Boltanski, L., \& Chamboredon, J. C. (1963). La Banque et sa clientèle. Paris: Centre de sociologie européenne.

Bowker, G. C., \& Star, S. L. (2000). Sorting things out: Classification and its consequences. The MIT Press.

Breen, R. (2005). Foundations of a neo-Weberian class analysis. In E. O. Wright (Ed.), Approaches to class analysis (pp. 31-50). Cambridge: Cambridge University Press.

Burchell, G., Gordon, C., \& Miller, P. (1991). The foucault effect: Studies in governmentality (1st ed.). University Of Chicago Press.

Caplovitz, D. (1963). The poor pay more: Consumer practices of low-income families. Free Press of Glencoe.

Carrns, A. (2012, November 6). Secrets of high credit scorers. New York Times (p. B4).

Carruthers, B. (2013). From uncertainty toward risk: The case of credit ratings. Socio-Economic Review, 1-27.

Carruthers, B., \& Cohen, B. (2010). Noter le crédit: Classification et Cognition aux Etats-Unis. Genèses, 2(79), 48-73.

Carruthers, B. G., Guinnane, T. W., \& Lee, Y. (2012). Bringing "honest capital" to poor borrowers: The passage of the U.S. Uniform Small Loan Law, 1907-1930. Journal of Interdisciplinary History, 42(3), 393-418.

Caskey, J. P. (1994). Fringe banking: Check-cashing outlets, pawnshops, and the poor. Russell Sage Foundation.

Cohen-Cole, E. (2011). Credit card redlining. Review of Economics and Statistics, 93(2), 700-713.

Collins, P. H. (1990). Black feminist thought: Knowledge, consciousness and the politics of empowerment. HarperCollins Publishers Ltd..

Conley, D. (1999). Being black, living the red. Race, wealth and social policy in America. University of California Press.

Cooper, D. J., \& Sherer, M. J. (1984). The value of corporate accounting reports: Arguments for a political economy of accounting. Accounting, Organizations and Society, 9(3), 207-232.

Desmond, M. (2012). Eviction and the reproduction of urban poverty. American Journal of Sociology, 118(1), 88-133.

Dimaggio, P. J., \& Powell, W. W. (1983). The iron cage revisited: Institutional isomorphism and collective rationality in organizational fields. American Sociological Review, 48(2), 147-160.

Erikson, R., \& Goldthorpe, J. H. (1993). The constant flux: A study of class mobility in industrial societies. Oxford: Oxford University Press.

Espeland, W., \& Sauder, M. (2007). Rankings and reactivity. How public measures recreate social worlds. American Journal of Sociology, 113(1), $1-40$.

Espeland, W., \& Stevens, M. (1998). Commensuration as a social process. Annual Review of Sociology, 24, 312-343.

FDIC (2009a). National survey of unbanked and underbanked households. Federal Deposit Insurance Corporation.

FDIC (2009b). Survey of unbanked and underbanked households (report). Federal Deposit Insurance Corporation.

FINRA (2009). National financial capability study. Finra Investor Education Foundation.

Fligstein, N., \& Goldstein, A. (2010). The anatomy of the mortgage securitization crisis. In M. Lounsbury \& P. M. Hirsch (Eds.), Markets on trial: The economic sociology of the US financial crisis. Emerald Group Publishing Limited.

Foucault, M. (2012). Discipline and punish: The birth of the prison. New York, NY: Random House.

Fourcade, M., \& Healy, K. (2013). Credit scores and the moralization of inequality. In Paper presented at the annual conference of the American Sociological Association (August).

FRB (2007). Report to congress on credit scoring and its effects on the availability and affordability of credit. Board of Governors of the Federal Reserve System.

Freund, D. M. P. (2010). Colored property: State policy and white racial politics in suburban America. University Of Chicago Press.

Fridman, D. (2010). From rats to riches: Game playing and the production of the capitalist self. Qualitative Sociology, 33(4), 423-446. 
FTC (2007). Credit-based insurance scores: impact on consumers of automobile insurance. A report to congress. Federal Trade Commission.

Furletti, M. (2002). An overview and history of credit reporting. Available at SSRN 927487.

Graeber, D. (2010). Debt: The first 5,000 years. Melville House.

Graves, S. M. (2003). Landscapes of predation, landscapes of neglect: A location analysis of payday lenders and banks. The Professional Geographer, 55(3), 303-317.

Grow, B., \& Epstein, K. (2007, May 21). The poverty business. Business Week.

Gruenstein Bocian, D., Li, W., Reid, C., \& Quercia, R. (2012). Lost ground, 2011: Disparities in mortgage lending and foreclosure. Center for Responsible Lending.

Grusky, D. B., \& Sørensen, J. B. (1998). Can class analysis be salvaged? American Journal of Sociology, 103(5), 1187-1234.

Guseva, A., \& Rona-Tas, A. (2001). Uncertainty, risk, and trust: Russian and American credit card markets compared. American Sociological Review, 623-646.

Hacker, J. S. (2008). The great risk shift: The new economic insecurity and the decline of the American Dream, rev. and exp. ed. $m$.

Hacking, I. (1986). Making up people. In T. Heller, M. Sosna, \& D. Wellberry (Eds.), Reconstructing individualism: Autonomy, individuality, and the self in Western thought (pp. 222-236). Stanford, CA: Stanford University Press.

Hall, P. A., \& Soskice, D. W. (2001). Varieties of capitalism: The institutional foundations of comparative advantage. Wiley Online Library.

Harvey, D. (2007). The limits to capital (Updated ed.). Verso.

Haveman, H., \& Rao, H. (1997). Structuring a theory of moral sentiments: Institutional and organizational coevolution in the early thrift industry. American Journal of Sociology, 102, 1606-1651.

Hilsenrath, J. (2012, June 19). Fed wrestles with how best to bridge U.S. Credit Divide. Wall Street Journal.

Hopwood, A. (1994). Accounting and the pursuit of efficiency. London: Sage.

Hsia, D. C. (1978). Credit scoring and the equal credit opportunity act. Hastings LJ, 30, 371.

Hyman, L. (2011). Debtor nation: The history of America in red ink. Princeton, NJ: Princeton University Press.

Krippner, G. R. (2012). Capitalizing on crisis: The political origins of the rise of finance. Harvard University Press.

Langley, P. (2009). The everyday life of global finance: Saving and borrowing in Anglo-America. Oxford: Oxford University Press.

Lazarus, J. (2012). L'épreuve du crédit: Banques, banquiers, clients. Paris: Calmann-Lévy.

Leyshon, A., \& Thrift, N. (1995). Geographies of financial exclusion: Financial abandonment in Britain and the United States. Transactions of the Institute of British Geographers, 312-341.

Leyshon, A., \& Thrift, N. (1999). Lists come alive: Electronic systems of knowledge and the rise of credit-scoring in retail banking. Economy and Society, 28(3), 434-466.

Loveman, M. (forthcoming). National colors: Racial classification and the state in Latin America. Oxford University Press.

Lusardi, A. (2011). Americans' financial capability. NBER working paper, 14808.

Lusardi, A., \& Tufano, P. (2009). Debt literacy, financial experiences, and overindebtedness. NBER working paper, 17107.

Marron, D. (2007). 'Lending by numbers': Credit scoring and the constitution of risk within American consumer credit. Economy and Society, 36(1), 103-133.

Marron, D. (2009). Consumer credit in the United States: A sociological perspective from the 19th century to the present. Palgrave Macmillan.

Marx, K. (1981). Capital (Vol. III). Harmondsworth: Penguin.

Massey, D. S. (2008). Categorically unequal: The American stratification system. Russell Sage Foundation Publications.

Melzer, B. T. (2011). The real costs of credit access: Evidence from the payday lending market*. The Quarterly Journal of Economics, 126(1), $517-555$.

Mian, A., \& Sufi, A. (2009). The consequences of mortgage credit expansion: Evidence from the US mortgage default crisis. The Quarterly Journal of Economics, 124(4), 1449-1496.

Mikes, A. (2009). Risk management and calculative cultures. Management Accounting Research, 20(1), 18-40.

Miller, P. (1992). Accounting and objectivity: The invention of calculating selves and calculable spaces. Annals of Scholarship, 9(1/2), 61-86.

Miller, M. J. (2003). Credit reporting systems and the international economy. The MIT Press.

Miller, P., \& O'Leary, T. (1987). Accounting and the construction of the governable person. Accounting, Organizations and Society, 12(3), 235-265.
Muniesa, F., Millo, Y., \& Callon, M. (2007). An introduction to market devices. The Sociological Review, 55, 1-12.

Newman, K., \& Chen, V. T. (2007). The missing class: Portraits of the near poor in America. Boston: Beacon Press.

Oliver, M., \& Shapiro, T. (2006). Black wealth/white wealth: A new perspective on racial inequality. Routledge.

Pager, D. (2007). Marked: Race, crime, and finding work in an era of mass incarceration. University of Chicago Press.

Poon, M. (2007). Scorecards as devices for consumer credit: The case of Fair, Isaac \& Company Incorporated. The Sociological Review, 55, 284-306.

Poon, M. (2009). From new deal institutions to capital markets: Commercial consumer risk scores and the making of subprime mortgage finance. Accounting, Organizations and Society, 34(5), 654-674.

Poon, M. (2013). Statistically discriminating without discrimination. Working paper. London School of Economics.

Porter, T. (1995). Trust in numbers. The pursuit of objectivity in science and public life. Princeton, NJ: Princeton University Press.

Power, M. (2011). Organized uncertainty: Designing a world of risk management. Oxford: Oxford University Press.

Prasad, M. (2013). The land of too much: American abundance and the paradox of poverty. Harvard University Press.

Quinn, S. L. (2011). Government policy, housing, and the origins of securitization, 1780-1968. PhD Dissertation, Department of Sociology, University of California, Berkeley.

Reskin, B. (2012). The race discrimination system. Annual Review of Sociology, 38, 17-35.

Roy, A. (2010). Poverty capital: Microfinance and the making of development. Taylor \& Francis.

Ruef, M., \& Patterson, K. (2009). Credit and classification: The impact of industry boundaries in nineteenth-century America. Administrative Science Quarterly, 54(3), 486-520.

Schneider, D., \& Tufano, P. (2007). New savings from old innovations: Asset building for the less affluent. Financing low-income communities: Models, obstacles and future directions. New York: Russell Sage.

Schor, P. (2009). Compter et classer: Histoire des recensements Américains. Editions de l'Ecole Pratiques de Hautes Etudes en Sciences Sociales.

Scott, J. C. (1999). Seeing like a state: How certain schemes to improve the human condition have failed. Yale University Press.

Sherman, M. (2009). A short history of financial deregulation in the United States. CEPR report (July).

Silver-Greenberg, J. (2012). Perfect 10? Never mind that. Ask her for her credit score (p. A1). New York Times.

Skeel, D. A. (2001). Debt's dominion: A history of bankruptcy law in America. Princeton University Press.

Skiba, P., \& Tobacman, J. (2009). Do payday loans cause bankruptcy? Vanderbilt Law and Economics Research Paper, 11-13).

Soederberg, S. (2012). The US debtfare state and the credit card industry: Forging spaces of dispossession. Antipode, 45(2), 493-512.

Starr, P. (1992). Social categories and claims in the liberal state. Social Research, 59(2), 263-295.

Steensland, B. (2010). Moral classification and social policy. In S. Hitlin, \& S. Vaisey (Eds.), The handbook on the sociology of morality (pp. 45568). New York, NY: Springer.

Stegman, M. A., \& Faris, R. (2003). Payday lending: A business model that encourages chronic borrowing. Economic Development Quarterly, $17(1), 8-32$

Sullivan, T. A., Westbrook, J. L., \& Warren, E. (1999). As we forgive our debtors: Bankruptcy and consumer credit in America. Beard Books.

Sullivan, T. A., Warren, E., \& Westbrook, J. L. (2006). Less stigma or more financial distress: An empirical analysis of the extraordinary increase in bankruptcy filings. Stanford Law Review, 59(2), 213-256.

Tilly, C. (1999). Durable inequality. University of California Press.

Trumbull, G. (2012). Credit access and social welfare: The rise of consumer lending in the United States and France. Politics E Society, 40(1), 9-34.

Vargha, Z. (2011). From long-term savings to instant mortgages: Financial demonstration and the role of interaction in markets. Organization, $18(2), 215-235$.

Venkatesh, S. A. (2008). Off the books: The underground economy of the urban poor. Harvard University Press.

Wacquant, L. (2009). Punishing the poor: The neoliberal government of social insecurity. Duke University Press.

Weber, M. (1978a). Economy and society: An outline of interpretive sociology (Vol. 1). Berkeley: University of California Press.

Weber, M. (1978b). Economy and society: An outline of interpretive sociology (Vol. 2). Berkeley: University of California Press. 
Weller, C. (2009). Credit access, the costs of credit and credit market discrimination. The Review of Black Political Economy, 36(1), 7-28.

Weller, C. (2012). Unburdening America's middle class. Challenge, 55(1), 23-52.

Wolff, E. N. (2010). Rising profitability and the middle class squeeze. Science \& Society, 74(3), 429-449.
Wolff, E. N. (2012). The asset price meltdown and the wealth of the middle class. NBER working paper, 18559.

Wright, E. O. (1985). Classes. Verso London. 